\section{Heritability of morpho-agronomic traits in ornamental pepper}

\author{
Mayana Ferreira Nascimento ${ }^{1^{*}}$, Elizanilda Ramalho do Rêgo ${ }^{2}$, \\ Naysa Flávia Ferreira do Nascimento², Pakizza Sherma da Silva \\ Leite ${ }^{3}$, Fernando Luiz Finger ${ }^{1}$, Claudio Horst Bruckner ${ }^{1}$ and \\ Mailson Monteiro do Rêgo ${ }^{2}$
}

\begin{abstract}
This study was conducted to identify the allelic interactions and genetic effects involved in genetic control of quantitative traits in Capsicum annuum. Six generations $\left(P_{1}, P_{2}, F_{1}, F_{2}, B C_{1}\right.$ and $\left.B C_{2}\right)$ were used to study the variances, means and allelic interactions of 16 quantitative traits evaluated. The additive part of the phenotypic variance found for plant height, number of peppers per plant, days to flowering and days to fruiting lead to the conclusion that phenotypic selection in the $\mathrm{F}_{2}$ generation are likely effective in obtaining genetic gains. According to the reduced model, the traits of canopy width, fruit width and number of seeds per fruit were not influenced by epistatic effects, but only by additive and dominant effects, which allows selection of superior individuals in segregating generations or improvement of these traits by means of hybridization.
\end{abstract}

Keywords: Chilli, full model, additive-dominant model, breeding.

\section{INTRODUCTION}

The genus Capsicum comprises five domesticated species: Capsicum annuum, $C$. baccatum, $C$. chinense, $C$. frutescens and $C$. pubescens. Capsicum annuum has the greatest economic importance among the species cultivated in Brazil (Pickersgill 1971). Pepper is one of the most important vegetables in the world due to its high versatility and wide range of application in industry, in cooking and for decoration (Silvar and García-González 2017).

The Capsicum annuum species is largely sold in pots as an ornamental plant. The cultivation of peppers in pots for ornamentation purposes has increased considerably all over the world. Ornamental peppers can also be used for making canned or dry goods (Nascimento et al. 2014, Finger and Pereira 2016).

Early maturity, high-yielding, small-sized cultivars with straight, colorful, attractive peppers are the main goal of a breeding program for ornamentation purposes (Rêgo et al. 2009, Rêgo and Rêgo 2016). Breeding programs of the Capsicum species can be initiated from hybridization, or developed from the selection of plants within preexisting populations.

The first step in a successful plant breeding program is selection of parents, and one of the criteria for selection of parents in hybrid production is genetic diversity. One of the ways to evaluate the magnitude and nature of the gene effects controlling a certain quantitative trait is through generation analysis,
Crop Breeding and Applied Biotechnology 19:3, 253-261, 2019 Brazilian Society of Plant Breeding. Printed in Brazil http://dx.doi.org/10.1590/198470332019v19n3a36 


\section{MF Nascimento et al.}

which allows for simultaneous evaluation of several generations or populations, including parents, hybrids $\left(F_{1}\right)$ and segregating populations like the $\mathrm{F}_{2}$ and those originating from backcrosses (Said 2014). This methodology makes it possible to evaluate the adequacy of the additive-dominant model for a certain trait and to estimate genetic parameters based on the measures and variances (Cruz and Regazzi 2001). Knowledge of the genetic system controlling various complex traits and the mode of their inheritance is crucial for effective transfer of desirable genes in resultant progenies, leading to the development of high-yielding cultivars and hybrids (Cruz and Regazzi 2001, Rêgo et al. 2009, Devi and Sood 2018). Thus, the aim of this study was to estimate the genetic parameters and heritability based on 22 quantitative traits in six generations $\left(\mathrm{P}_{1}, \mathrm{P}_{2}, \mathrm{~F}_{1}, \mathrm{~F}_{2}, \mathrm{BC}_{1}\right.$ and $\left.\mathrm{BC}_{2}\right)$ of ornamental pepper.

\section{MATERIAL AND METHODS}

The present study was conducted in a greenhouse in the Laboratory of Plant Biotechnology of the Center for Agricultural Sciences of the Federal University of Paraíba (Centro de Ciências Agrárias da Universidade Federal de Paraíba - CCAUFPB), Areia, PB, Brazil. Two accessions (UFPB 01 and UFPB 132) belonging to the germplasm bank of UFPB were used as parents. These accessions were crossed to produce $F_{1}$. The $F_{1}$ hybrids were backcrossed with their parents to generate the backcross progenies $\left(B C_{1}\right.$ and $\left.B C_{2}\right)$ and were self-pollinated to generate the $F_{2}$ generation. The six generations $\left(P_{1}, P_{2}\right.$, $F_{1}, F_{2}, B C_{1}$ and $B C_{2}$ ) were used to study the variances, means and allelic interactions of the quantitative traits. When the peppers reached the harvesting point, the seeds were removed and counted per pepper fruit. Crosses were performed according to Nascimento et al. (2012a).

The parents $\left(\mathrm{P}_{1}\right.$ and $\left.\mathrm{P}_{2}\right), \mathrm{F}_{1}$ and segregating generations $\left(\mathrm{F}_{2}, \mathrm{BC}\right.$ and $\left.\mathrm{BC}_{2}\right)$ were sown in 200-cell Styrofoam trays containing a commercial substrate (Plantmax). When the plants reached the stage of six pairs of definitive leaves, they were transplanted to $900-\mathrm{mL}$ pots $(13 \mathrm{~cm}$ height and $16 \mathrm{~cm}$ width), with one plant per pot. Crop treatments recommended for the species were applied whenever necessary.

Was planted ten replicates of hybrids and parents ( 72 plants in $\mathrm{BC}_{1}, 75$ plants in $\mathrm{BC}_{2}$ and 147 plants in $\mathrm{F}_{2}$ were used). Characterization of the 16 morpho-agronomic traits was based on the list of quantitative traits suggested by IPGRI (1995), with three observations per plant.

The following quantitative traits were evaluated: plant height $(\mathrm{PH}, \mathrm{cm})$, canopy width $(\mathrm{CW}, \mathrm{cm})$, first bifurcation height $(F B H, c m)$, stem width (SW, cm), leaf length $(L L, c m)$, leaf width $(L W, c m)$, corolla length $(C L, c m)$, days to flowering $\left(D F_{L}\right)$, fruit weight $\left(F_{R} W, g\right)$, fruit length $\left(F_{R} L, c m\right)$, fruit width $\left(F_{R} D, c m\right)$, pericarp thickness $(P T, c m)$, dry matter content (DMC), seed yield per fruit (SYF), fruit yield per plant (FYP) and days to fruiting $\left(D F_{R}\right)$. Dimension measurements were taken using a caliper. Weight data were taken on an analytical balance. Quantity values were obtained by counting.

Each one of the 16 quantitative traits listed above was subjected to generation analysis, in which the means, the additive $\left(\sigma_{a}^{2}\right)$, phenotypic $\left(\sigma_{f}^{2}\right)$, genetic $\left(\sigma_{g}^{2}\right)$ and environmental $\left(\sigma_{m}^{2}\right)$ variances and the variance due to dominance deviations $\left(\sigma_{d}^{2}\right)$ were estimated. The broad-sense $\left(h_{b}^{2}\right)$ and narrow-sense $\left(h_{n}^{2}\right)$ heritability estimates were also calculated.

For the full model, the effects of the means of all possible homozygotes $(\mathrm{m})$ and the additive $(\mathrm{d})$, dominant $(\mathrm{h})$ and epistatic effects were estimated: additive $\times$ additive (i), additive $\times$ dominant (j) and dominant $\times$ dominant $(\mathrm{I})$. For the additive-dominant model, the additive (a) and dominant (d) effects and the effects of the mean $(\mathrm{m})$ were estimated.

The following formulas were utilized to obtain these results.

Phenotypic variance in $\mathrm{F}_{2}$ :

$\hat{\sigma}_{f(F 2)}^{2}=\hat{\sigma}_{F 2}^{2}$

Environmental variances:

$\hat{\sigma}_{m(F 2)}^{2}=\frac{2 \hat{\sigma}_{F 1}^{2}+\hat{\sigma}_{P 1}^{2}+\hat{\sigma}_{P 2}^{2}}{4}, \quad \hat{\sigma}_{m(B C 1)}^{2}=\frac{\hat{\sigma}_{F 1}^{2}+\hat{\sigma}_{P 1}^{2}}{2} \quad \hat{\sigma}_{m(B C 2)}^{2}=\frac{\hat{\sigma}_{F 1}^{2}+\hat{\sigma}_{P 2}^{2}}{2}$

Genetic variance in $\mathrm{F}_{2}$ :

$\hat{\sigma}_{g(F 2)}^{2}=\hat{\sigma}_{f(F 2)}^{2}-\hat{\sigma}_{m(F 2)}^{2}$ 
Additive variance:

$\hat{\sigma}_{a}^{2}=\hat{\sigma}_{f(F 2)}^{2}-\left[\hat{\sigma}_{f(B C 1)}^{2}=\hat{\sigma}_{f(B C 2)}^{2}\right]$

Where

$\hat{\sigma}_{g(B C 1)}^{2}=\hat{\sigma}_{f(B C 1)}^{2}-\hat{\sigma}_{m(B C 1)}^{2}$

$\hat{\sigma}_{g(B C 2)}^{2}=\hat{\sigma}_{f(B C 2)}^{2}-\hat{\sigma}_{m(B C 2)}^{2}$

Variance due to dominance deviations:

$\hat{\sigma}_{d}^{2}=\hat{\sigma}_{g(F 2)}^{2}-\hat{\sigma}_{a}^{2}$

Analysis of the means of the generations - full model:

$\hat{\mathrm{m}}=\frac{1}{2} \bar{P}_{1}+\frac{1}{2} \bar{P}_{2}+4 \bar{F}_{2}-2 \overline{\mathrm{BC}}_{1}-2 \overline{\mathrm{BC}}_{2}$

$\hat{\mathrm{d}}=\frac{1}{2} \bar{P}_{1}-\frac{1}{2} \bar{P}_{2}$

$\hat{\mathrm{h}}=-\frac{3}{2} \bar{P}_{1}-\frac{3}{2} \bar{P}_{2}-\bar{F}_{1}-8 \bar{F}_{2}+6 \overline{\mathrm{BC}}_{1}+6 \overline{\mathrm{BC}}_{2}$

$\hat{i}=-4 \bar{F}_{2}+2 \overline{\mathrm{BC}}_{1}+2 \overline{\mathrm{BC}}_{2}$

$\hat{j}=-\bar{P}_{1}+\bar{P}_{2}+2 \overline{\mathrm{BC}}_{1}-2 \overline{\mathrm{BC}}_{2}$

$\hat{i}=\bar{P}_{1}+\bar{P}_{2}+2 \bar{F}_{1}+4 \bar{F}_{2}-4 \overline{\mathrm{BC}}_{1}-4 \overline{\mathrm{BC}}_{2}$

All the effects of the two models were subjected to the t-test of significance at the $5 \%$ probability level. All statistical analyses were performed using the GENES software (Cruz 2006).

\section{RESULTS AND DISCUSSION}

\section{Averages of the six generations}

The mean values of the $F_{1}$ generation were similar to those of the parents for $P H, C W, F B H, S W, L L, C L, F_{R} L, P T$ and $\mathrm{DF}_{\mathrm{R}}$ (Figure 1), indicating the occurrence of additive interaction. According to Marame et al. (2009a), when the favorable additive alleles are fixed within a locus, genotypes in early maturity generations can be selected. Similar results were found by Geleta and Labuschagne (2004) and Rêgo et al. (2009), working with Capsicum annuum L. and Capsicum baccatum, respectively, for pericarp thickness. Rodrigues et al. (2012) found similar results for plant height in C. baccatum. Geleta and Labuschagne (2004) found greater predominance of effects of an additive nature on the control of days to fruiting in studies conducted with Capsicum annuum L.

Lower mean values were found in the $F_{1}$ generation than in the parents for leaf width (LW) and fruit dry matter content (DMC) (Figure 1). These traits showed negative heterosis. Analyzing components of fruit production and fruit quality in a diallel (Capsicum annuum), Nascimento et al. (2014) showed non-additive effects for fruit dry matter content.

The means of $F_{1}$ generation were higher than those of the parents for $F_{R} D$, SYF and FYP (Figure 1). These findings indicated the occurrence of positive heterosis or hybrid vigor. The occurrence of heterosis can be explained by the hypothesis of dominance, overdominance or epistasis. Similar results were found by Nascimento et al. (2014) and Santos et al. (2014) in studies with Capsicum annuum for SYF and FYP. In studies with Capsicum baccatum, Rêgo et al. (2009) and Rodrigues et al. (2012) found similar results for $F_{R} W$.

The $F_{2}$ mean was lower than the mean of the parents for $L W, D F_{L}$ and $D F_{R}$. SYF and FYP had higher mean values in $F_{2}$ than in the parents (Figure 1). Transgressive individuals were found for all these traits. According to Wesp et al. (2008), transgressive segregation is the appearance of individuals in segregating generations that are out of the range of parents for each trait evaluated.

The traits of $D F_{L}$ and $D F_{R}$ are a measure of earliness and, as such, they should show minimum values. In the present 
study, transgressive segregants were obtained for both traits. Sharma et al. (2017), in studies with different genotypes of Capsicum annuum, also achieved transgressive. An understanding of genetic diversity among the parents is essential to obtain desirable transgressive segregants since diverse parents leads to high heterosis (Khodadadi et al. 2011). According to Rêgo et al. (2009), it is possible to select the transgressive individuals in the segregating generation and continue with the breeding program until plants with the appropriate height for potting are obtained.

\section{Gene effects and heritability}

For $\mathrm{PH}, \mathrm{DF}_{\mathrm{L}^{\prime}}$ SYF, FYP and $\mathrm{DF}_{\mathrm{R}^{\prime}}$ the additive effects were higher than the dominant ones (Table 1). This result was also proven by the high broad- and narrow-sense heritability values for these traits (Table 1). Marame et al. (2009a, b), Nascimento et al. (2012b) and Santos et al. (2014) reported similar results in their studies with C. annuum species. For these traits, it is possible to obtain genetic gains with phenotypic selection in early segregating generations.

High seed yield per fruit is of great interest for the seed market, because even plants with few peppers can produce a satisfactory number of seeds. Marame et al. (2009a, b), Nascimento et al. (2012b) and Santos et al. (2014) reported similar results in a biometric analysis of peppers (C. annuum) for $\mathrm{PH}$. For $\mathrm{DF}_{\mathrm{L}^{\prime}}$, contrasting results were reported by Rêgo et al. (2012a) in studies of heritability for early maturity in C. annuum.

For FYP, Rêgo et al. (2011) and Thakur et al. (2019), evaluating C. baccatum and C. annuum respectively, reported high broad-sense heritability values, revealing little influence of the environment and highly contrasting parents. Conflicting results for FYP by Bento et al. (2016) with C. baccatum, who showed low values for broad- and narrow-sense heritability for this trait.

The effects of dominance prevailed for SW, LL and LW (Table 1). These findings explain the high broad-sense heritability and low narrow-sense heritability values, revealing the difficulty in the selection of genes of interest in the early segregating generations (Table 1). Santos et al. (2014) showed similar results for SW, and Stommel and Griesbach (2008) also report similar results for LW. This may be attributed to the fact that these authors worked with $C$. annuum species. For these traits, production of hybrids would be the best alternative to decrease the length and width of the leaves. When the effects due to dominance are predominant, the production of hybrids exploiting heterosis or heterobeltiosis is the best alternative for the breeding program.

Table 1. Means (M) and standard error (SE) for 16 quantitative plant and fruit traits in parents, $F_{1}, F_{2}$ and $B C_{1}$ and $B C_{2}$ backcrosses obtained from crosses between accessions of Capsicum annuum 01 and 132

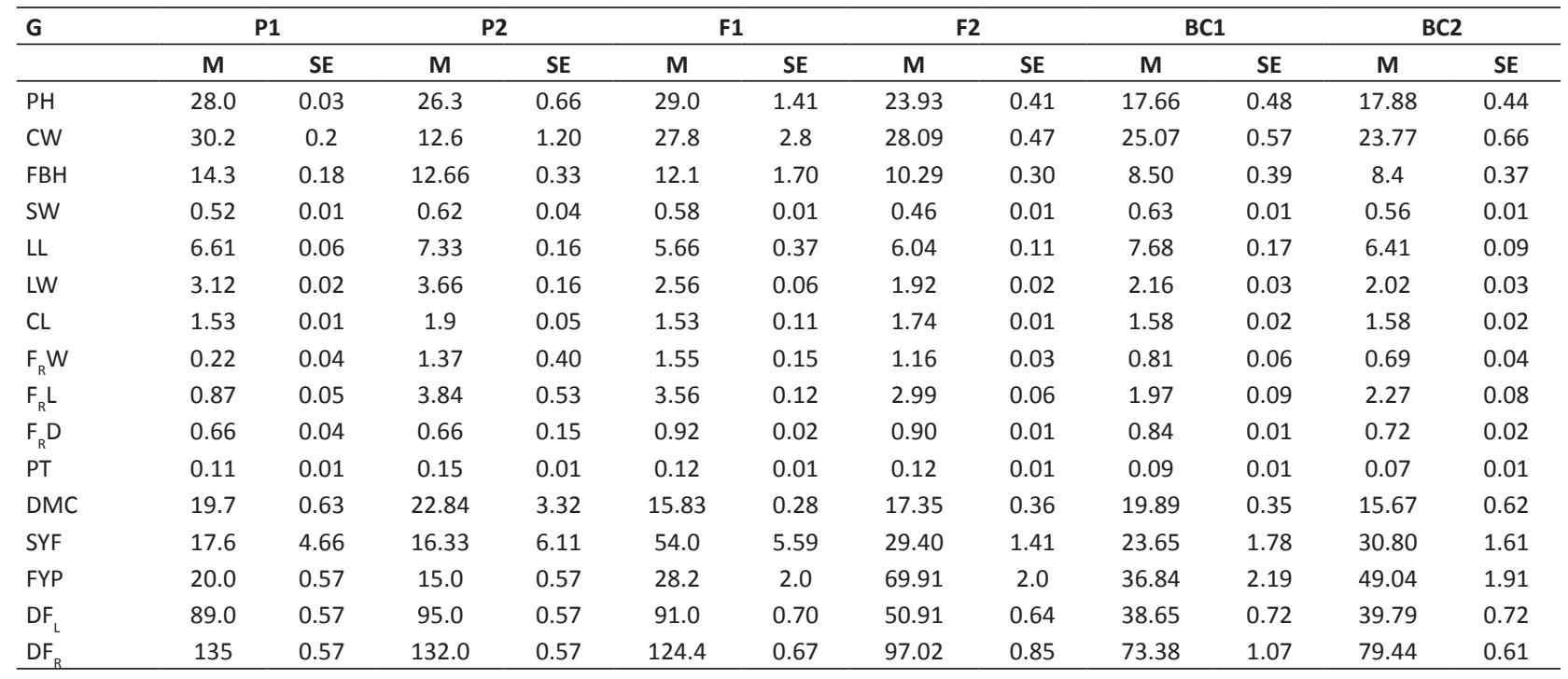

PH (cm) - plant height; CW (cm) - canopy width; FBH (cm) - first bifurcation height; SW (cm) - stem width; LL (cm) - leaf length; LW (cm) - leaf width; CL (cm) - corolla length; $F_{R} W(g)$ - fruit weight; $F_{B} L(\mathrm{~cm})$ - fruit length; $F_{R} D(\mathrm{~cm})$ - fruit width; PT $(\mathrm{cm})$ - pericarp thickness; DMC $(\mathrm{cm})$ - dry matter content; SYF - seed yield per fruit; FYP - fruit yield per plant; $\mathrm{DF}_{\mathrm{L}}$ - days to flowering; $\mathrm{DF}_{\mathrm{R}}$ - days to fruiting. $\mathrm{SE}$ : standard error. $\mathrm{M}$ - mean. $\mathrm{G}$ - generation. 
Environmental variance was responsible for the greater percentage of phenotypic variance for $\mathrm{CW}, \mathrm{FBH}, \mathrm{CL}, \mathrm{F}_{\mathrm{R}} \mathrm{W}$, $F_{R} L, F_{R} D, P T$ and $D M C$ (Table 1). The high value of environmental variance was reflected in broad- and narrow-sense heritability with lower values (Table 1). According to Passos et al. (2010), low heritability values indicate that the environment is exerting a strong influence on the phenotypic expression of the traits. For these traits, the selection of individuals based on the phenotype is inefficient due to little reliability of the genotype in passing on the desirable phenotype to the offspring. Conflicting data for CW were reported by Marame et al. (2009b) in studies on Capsicum annuum L. cv. annuum, and by Rêgo et al. (2011) on Capsicum baccatum. These authors showed higher values, above $70 \%$, for broad-sense heritability. These findings may be explained by the use of more divergent material as parents.

Contrasting results were reported by Nascimento et al. (2012b) and Santos et al. (2014), for FBH in studies of heritability in the ornamental pepper Capsicum annuum. These authors reported high broad-sense heritability values for the FBH trait. Plants with a small size and lower first bifurcation height, without the need for growth regulators, are desirable for ornamental plants (Rêgo et al. 2009). Thus, production of hybrids in this case aiming to decrease the FBH would be the best alternative.

Nascimento et al. (2012b) described broad-sense heritability values of more than $60 \%$ for $\mathrm{CL}$, in disagreement with the data found in this study. For these traits, one of the alternatives would be crossing more divergent individuals to increase genetic variance.

For fruit traits, several studies showed contrasting findings for heritability values regarding $F_{R} W$ and $F_{R} D$. Pessoa et al. (2018) and Yunandra et al. (2018), also in studies with Capsicum annuum, reported broad-sense heritability estimates above $70 \%$. Rêgo et al. (2011), working with C. baccatum, reported a broad-sense heritability estimate greater than $90 \%$ for this $F_{R} W$. These differences in results can be explained by the fact that different parents with greater contrast for the trait were used. Also for $F_{R} L$, Marame et al. (2009a, b) reported conflicting data in studies with $C$. annuum $\mathrm{cv}$. annuum L., in which the authors found high broad- and narrow-sense heritability values. According to Rêgo et al. (2011), fruitsize traits are negatively correlated with fruit yield per plant in ornamental peppers. Selecting high-yielding plants, we can obtain plants with smaller and less heavy peppers since the fruit yield per plant has high narrow-sense heritability.

Regarding PT and DMC, Bento et al. (2016), in studies with Capsicum baccatum cv. Pendulum, observed low broad-and narrow-sense heritability values, corroborating those reported in the present study. In contrast, Santos et al. (2014) and Thakur et al. (2019), in studies with Capsicum annuum, reported high broad sense heritability for PT values; and Rêgo et al. (2011), also working with C. baccatum, found broad-sense heritability values higher than $81.7 \%$ for both traits.

Table 2. Estimates of genetic parameters for plant and fruit traits in a segregating population of ornamental peppers (Capsicum annuum) obtained from the cross between accessions 01 and 132

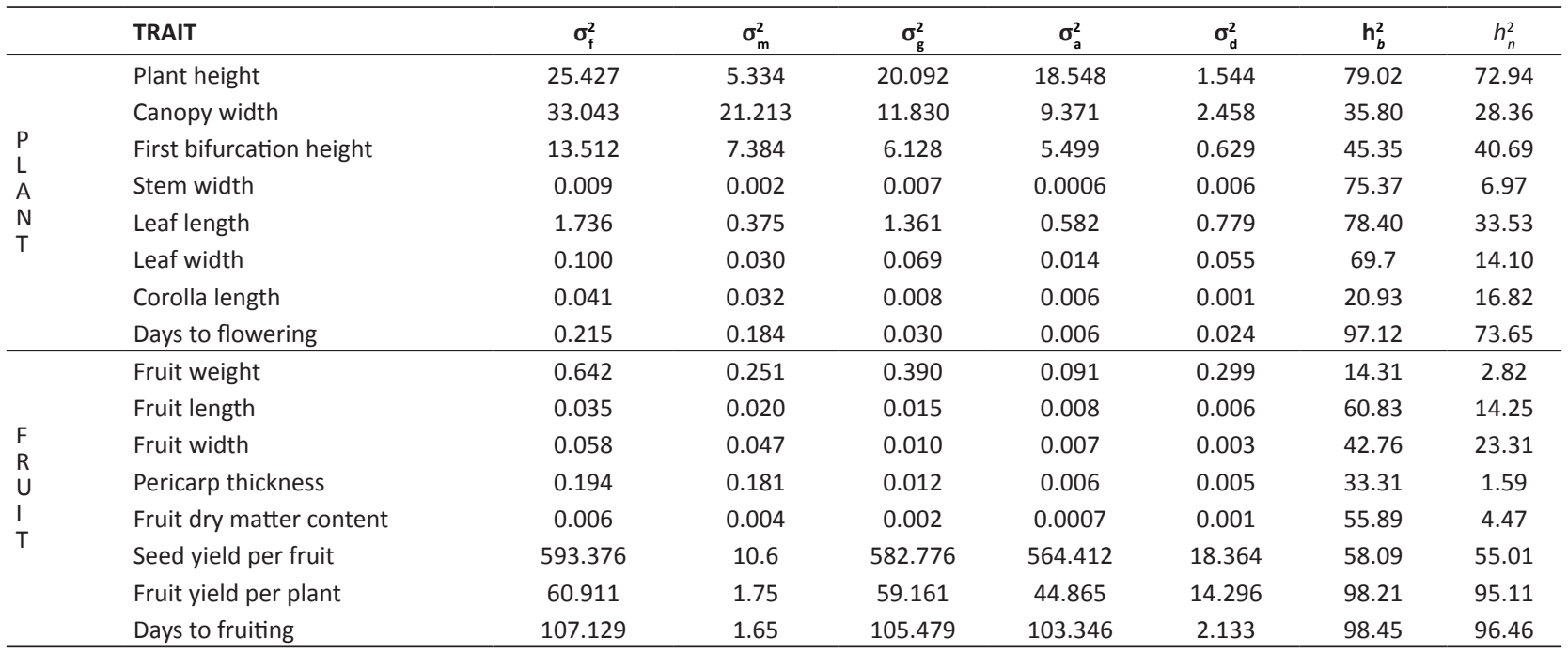

$\sigma_{f}^{2}$ - phenotypic variance; $\sigma_{m}^{2}$ - environmental variance; $\sigma_{g}^{2}$ - genotypic variance; $\sigma_{a}^{2}$ - additive variance; $\sigma_{d}^{2}$ - dominance variance; $h_{b}^{2}$ - broad-sense heritability, in $\%$; $h_{n}^{2}$ narrow-sense heritability, in \%. 


\section{Adequacy of models}

The additive-dominance model explained only three variables: CW (81.7\%), $\mathrm{F}_{R} \mathrm{D}$ (71.1\%) and SYF (84.1\%) (Table 3). Santos et al. (2014) and Bento et al. (2016) reported the adequacy of the additive-dominant model controlling the CW and $F_{R} D$ traits, respectively. Significant values for all traits were found for $m$ and $d$ in the additive-dominant model, except for $F_{R} D$. The dominant effects (h) were significant for all traits (Table 3). Santos et al. (2014), in studies with C. annuum, and Bento et al. (2016), with $C$. baccatum, reported the adequacy of the additive-dominant model controlling the CW and $F_{R} D$ traits, respectively. According to Cruz and Regazzi (2001), high $R^{2}$ estimates express the degree of similarity between the estimated and observed values, indicating the accuracy of the model adopted.

The $\mathrm{CW}$ trait showed greater contributions from the additive effects $(d)$. Different results were reported for $C$. annuum (Marame et al. 2009a), C. baccatum (Rego et al. 2009a) and C. annuum (Santos et al. 2014) for this trait. Conversely, Rêgo et al. (2012b) found similar results for this trait. Based on values found in this study, it is possible to obtain superior homozygous genotypes through selection from early generations.

Dominant effects ( $h$ ) contributed more to $F_{R} D$ and SYF (Table 3 ). The greater contributions of the dominance effects with positive values indicate that exploitation of hybrid vigor aiming to obtain fruit with greater fruit width and seed yield is the best alternative for breeding programs, for production of seeds for sale and for preservation in germplasm banks. Similar results were reported by Hasanuzzaman et al. (2012), working with Capsicum annuum.

It is important to maintain harmony between plant architecture and fruit size, and fruit width should be proportional to plant height. For that reason, after production of hybrids, genotypes with the lowest values for fruit diameter should be selected and successively self-pollinated until obtaining homozygous lines with reduced values for this trait. Previous reports have shown that $F_{R} D$ can be governed by additive effects (Rêgo et al. 2009, Nascimento et al. 2014, Yunandra et al. 2018) and also by non-additive effects (Hasanuzzaman et al. 2012). According to Hasanuzzaman et al. (2012), these different results may be due to genetic differences of the parents and the different environments used.

The full model explained the traits of $\mathrm{PH}, \mathrm{FBH}, \mathrm{SW}, \mathrm{LL}, \mathrm{LW}, \mathrm{CL}, \mathrm{DF}_{L^{\prime}}, \mathrm{F}_{\mathrm{R}} \mathrm{W}, \mathrm{F}_{\mathrm{R}} \mathrm{L}, \mathrm{PT}, \mathrm{DMC}, \mathrm{FYP}$ and $\mathrm{DF} \mathrm{R}_{\mathrm{R}}$ (Table 4), as shown by of the low estimates of $\mathrm{R}^{2}(1.01 \%$ to $53.8 \%)$ (Table 4). Bnejdi et al. (2009), in studies with a segregating generation of Capsicum annuum, also reported failure in the additive-dominant model; they believed that this failure was due to the interaction among the genes that regulate the traits involved.

Table 3. Gene effects for the additive-dominant model in 16 plant and fruit traits in ornamental pepper

\begin{tabular}{|c|c|c|c|c|c|c|}
\hline \multirow[b]{2}{*}{ Effect } & \multicolumn{6}{|c|}{ ADDITIVE-DOMINANT MODEL } \\
\hline & $\mathrm{PH}\left(\mathbf{R}^{2}\right)$ & $\mathrm{CW}\left(\mathrm{R}^{2}\right)$ & FBH $\left(\mathbf{R}^{2}\right)$ & $S W\left(R^{2}\right)$ & $\mathrm{LL}\left(\mathbf{R}^{2}\right)$ & $\operatorname{LW}\left(R^{2}\right)$ \\
\hline $\mathrm{m}$ & $26.73 * *(97.06)$ & $23.95^{* *}(93.21)$ & $13.47^{* *}(95.49)$ & $0.49 * *(98.98)$ & $6.82 * *(99.72)$ & $2.56 * *(94.47)$ \\
\hline$d$ & $1.29 * *(0.22)$ & $6.10 * *(6.32)$ & $0.80 * *(0.37)$ & $0.02 * *(0.36)$ & $-0.16 *(0.05)$ & $0.43 * *(3.0)$ \\
\hline $\mathrm{h}$ & $-11.29 * *(2.70)$ & $3.75^{* *}(0.45)$ & $-8.03 * *(4.12)$ & $0.07 * *(0.65)$ & $-0.82 * *(0.21)$ & $-0.80 * *(2.51)$ \\
\hline Total (\%) & 1.01 & 81.7 & 21.1 & 2.31 & 30.43 & 9.5 \\
\hline Effect & $C L\left(R^{2}\right)$ & $F_{R} W\left(R^{2}\right)$ & $F_{R} L\left(R^{2}\right)$ & $F_{R} D\left(R^{2}\right)$ & PT $\left(R^{2}\right)$ & $\mathrm{DMC}\left(\mathrm{R}^{2}\right)$ \\
\hline $\mathrm{h}$ & $-.007(0.0003)$ & $1.61 * *(94.35)$ & $2.25 * *(40.79)$ & $0.24 * *(3.99)$ & $-0.01(0.18)$ & $-2.59 * *(1.11)$ \\
\hline Total (\%) & 53.8 & 16.7 & 38.3 & 71.1 & 4.4 & 6.8 \\
\hline Effect & & $\operatorname{SYF}\left(R^{2}\right)$ & $\mathrm{FYP}\left(\mathrm{R}^{2}\right)$ & $\mathrm{DF}_{1}\left(\mathrm{R}^{2}\right)$ & $D^{2} F_{R}\left(R^{2}\right)$ & \\
\hline $\mathrm{m}$ & & $13.81 * *(40.94)$ & $18.52 * *(81.53)$ & $79.83 * *(97.40)$ & $123.19 * *(98.61)$ & \\
\hline$d$ & & $-4.48 *(10.45)$ & $2.18^{* *}(1.13)$ & $-3.06 * *(0.14)$ & $4.56^{* *}(0.13)$ & \\
\hline
\end{tabular}

$\mathrm{PH}(\mathrm{cm})$ - plant height; CW (cm) - canopy width; FBH (cm) - first bifurcation height; SW (cm) - stem width; LL (cm) - leaf length; LW (cm) - leaf width; CL (cm) - corolla length; $F_{B} W(g)$ - fruit weight; $F_{R} L(\mathrm{~cm})$ - fruit length; $F_{R} D(\mathrm{~cm})$ - fruit width; PT (cm) - pericarp thickness; DMC (cm) - fruit dry matter content; SYF - seed yield per fruit; FYP - fruit yield per plant; $D F_{L}$ - days to flowering; $D F_{R}$ - days to fruiting.

$\mathrm{m}=$ mean of homozygotes, $\mathrm{d}=$ additive, $\mathrm{h}=$ dominant.

$* *, *$ significant at $1 \%$ and $5 \%$ probability level by the test. 
Heritability of morpho-agronomic traits in ornamental pepper

Table 4. Gene effects for the full model in 16 traits in ornamental pepper

\begin{tabular}{|c|c|c|c|c|c|c|c|}
\hline \multicolumn{8}{|c|}{ FULL MODEL } \\
\hline & $T / E$ & $\mathrm{~m}\left(\mathrm{R}^{2}\right)$ & $d\left(R^{2}\right)$ & $h\left(R^{2}\right)$ & $\mathrm{i}\left(\mathbf{R}^{2}\right)$ & $\mathrm{j}\left(\mathrm{R}^{2}\right)$ & $I\left(R^{2}\right)$ \\
\hline \multirow{5}{*}{$\begin{array}{l}P \\
L \\
A \\
N\end{array}$} & $\mathrm{PH}$ & $51.82 * *(47)$ & $0.85(0.52)$ & $-88.74 * *(21.53)$ & $-24.64 * *(10.96)$ & $-2.14(0.17)$ & $65.92 * *(19.46)$ \\
\hline & $\mathrm{CW}$ & $36.13 * *(37.84)$ & $8.76 * *(42.41)$ & $-23.81^{*}(2.16)$ & $-14.70 * *(6.61)$ & $-14.93 * *(9.96)$ & $15.47(0.98)$ \\
\hline & $\mathrm{FBH}$ & $20.89 * *(54.91)$ & $0.85 *(6.68)$ & $-33.59 * *(19.33)$ & $-7.37 * *(6.93)$ & $-1.49(0.56)$ & $24.80 * *(11.55)$ \\
\hline & SW & $0.04(0.29)$ & $-0.04(1.58)$ & $1.14 * *(26.07)$ & $0.52 * *(49.73)$ & $0.23 *(6.36)$ & $-0.60 * *(15.94)$ \\
\hline & LL & $2.97 * *(11.48)$ & $-0.36 *(7.62)$ & $9.60 * *(17.87)$ & $3.99 * *(21.28)$ & $3.26 * *(26.10)$ & $-6.92 * *(15.62)$ \\
\hline 1 & $\mathrm{DF}_{\mathrm{L}}$ & $138.78 * *(29.62)$ & $-3.0 * *(0.91)$ & $-303.67^{* *}(23.52)$ & $-46.78 * *(3.41)$ & $3.72(0.04)$ & $255.89 * *(42.46)$ \\
\hline \multirow{5}{*}{$\begin{array}{l}F \\
R \\
U \\
I \\
T\end{array}$} & $F_{R} W$ & $2.43^{* *}(34.12)$ & $-0.57 *(4.08)$ & $-4.20 * *(12.80)$ & $-1.63 * *(29.14)$ & $1.38 *(5.12)$ & $3.32 * *(14.71)$ \\
\hline & $F_{R} L$ & $5.81 * *(38.84)$ & $-1.48 * *(7.23)$ & $-9.05^{* *}(12.74)$ & $-3.46 * *(21.11)$ & $2.37 *(3.79)$ & $6.79 * *(16.26)$ \\
\hline & $F_{R} D$ & $1.14^{* *}(68.21)$ & $0.003(0.001)$ & $-0.74(3.80)$ & $-0.47 * *(22.28)$ & $0.23(1.35)$ & $0.52(4.33)$ \\
\hline & PT & $0.29 * *(47.37)$ & $-0.01(0.68)$ & $-0.50 * *(17.88)$ & $-0.16^{* *}(19.98)$ & $0.08^{* *}(2.87)$ & $0.33 * *(11.19)$ \\
\hline & $\mathrm{DF}_{\mathrm{B}}$ & $215.91^{* *}(38.85)$ & $1.5 *(0.20)$ & $-384.07^{* *}(21.37)$ & $-82.41^{* *}(5.71)$ & $-15.11^{* *}(0.51)$ & $292.55^{* *}(33.35)$ \\
\hline
\end{tabular}

$\mathrm{PH}(\mathrm{cm})$ - plant height; $\mathrm{CW}(\mathrm{cm})$ - canopy width; $\mathrm{FBH}(\mathrm{cm})$ - first bifurcation height; $\mathrm{SW}(\mathrm{cm})$ - stem width; LL $(\mathrm{cm})$ - leaf length; LW (cm) - leaf width; $\mathrm{CL}(\mathrm{cm})$ - corolla length; $F_{B} W(g)$ - fruit weight; $F_{B} L(c m)$ - fruit length; $F_{B} D(\mathrm{~cm})$ - fruit width; PT $(\mathrm{cm})$ - pericarp thickness; DMC $(\mathrm{cm})$ - fruit dry matter content; SYF - seed yield per fruit; FYP - fruit yield per plant; $D F_{L}$ - days to flowering; $D_{R}$ - days to fruiting.

$\mathrm{m}=$ mean of homozygotes, $\mathrm{d}=$ additive, $\mathrm{h}=$ dominant, $\mathrm{i}=$ additive $\times$ additive, $\mathrm{j}=$ additive $\times$ dominant, and $\mathrm{I}=$ dominant $\times$ dominant. $\mathrm{T} / \mathrm{E}=$ Trait $/$ Effect.

$* *, *$ significant at $1 \%$ and $5 \%$ probability level by the $t$ test.

Dominance effects $(\mathrm{h})$ and the epistatic dominance $\times$ dominance $(/)$ effects most contributed to the traits of $\mathrm{PH}, \mathrm{FBH}$, SW, LL, LW, CL, DF $\mathrm{L}^{\prime} \mathrm{F}_{\mathrm{R}} \mathrm{W}, \mathrm{F}_{\mathrm{R}} \mathrm{L}, \mathrm{PT}, \mathrm{DMC}, \mathrm{FYP}$ and $\mathrm{DF}_{\mathrm{R}}$ (Table 4). Marame et al. (2009a) and Anandhi and Abdul Khader (2011) reported similar results in studies with Capsicum for the traits of $P H, F Y P, F_{R} L$ and $F_{R} W$. The significance of the values for the dominance and dominance $\times$ dominance effects leads us to conclude that production of hybrids to decrease the magnitude of the traits would be the most efficient breeding strategy for development of new pepper cultivars. Because of gene interaction, selection in early generations might not be effective (Marame et al. 2009a). Juhász et al. (2009) and Santos et al. (2014) also found epistatic effects in the agronomic traits of peppers.

For FYP, the dominance effects $(h)$ and the epistatic additive $\times$ additive effects (i) were predominant (Table 3 ), indicating the possibility of heterosis breeding, as well as reciprocal recurrent selection and biparental mating, followed by selection for desirable segregants in subsequent generations, as a strategy to improve the population. According to Valentini et al. (2011), in autogamous plants such as peppers, high magnitudes of additive variance and the additive $x$ additive interaction make it possible to obtain satisfactory genetic gains.

The DMC trait showed greater contributions from the additive $\times$ dominant genetic effect (Table 3), hybrid vigor should be by exploiting heterobeltiosis to higher values for the trait, increasing significantly the paprika production (Lasmar et al. 2019).

\section{CONCLUSION}

Transgressive segregants were obtained for all the traits evaluated, except for $F_{R} W, F_{R} L$ and PT; these traits are highly important for ornamental-pepper breeding programs that aim at producing new lines with the traits of interest.

The additive variance observed in the phenotypic variation found for the $\mathrm{PH}, \mathrm{FYP}, \mathrm{DF}_{\mathrm{L}}$ and $\mathrm{DF}_{\mathrm{R}}$ traits indicate that the selection of individuals in the $F_{2}$ generations through phenotypic selection must have been efficient and provided genetic gains.

The epistatic effects did not affect control of $C W, F_{R} D$ and SYF, only additive and dominant effects. Therefore, superior individuals can be selected in segregating generations or hybridization can be practiced. 


\title{
ACKNOWLEDGMENTS
}

\author{
The authors thank CAPES and CNPq for financial support and fellowship.
}

\section{REFERENCES}

Anandhi K and Abdul Khader KM (2011) Gene effects of fruit yield and leaf curl virus resistance in interspecific crosses of chilli (Capsicum annuum L. and C. frutescens L.). Journal of tropical agriculture 49: 107-109.

Bento CS, Rodrigues LSA, Sudré CP, Medeiros AM, Oliveira HS, Mathias VAS and Gonçalves LSA (2016) Determining the inheritance of agronomic traits in chili pepper. Horticultura Brasileira 34: 367-373.

Bnejdi F, Saadoun M, Allagui MB and Gazzah Mel (2009) Epistasis and heritability of resistance to Phytophthora nicotianae in pepper (Capsicum annuum L.). Euphytica 167: 39-44.

Cruz CD (2006) Programa genes: aplicativo computacional em genética e estatística. Editora UFV, Viçosa, 648p.

Cruz CD and Regazzi AJ (2001) Modelos biométricos aplicados ao melhoramento genético. Editora UFV, Viçosa, 390p.

Devi J and Sood S (2018) Genetic study of horticultural traits in bell pepper (Capsicum annuum var. grossum) through generation mean analysis. Agricultural Research 7: 112-119.

Finger FL and Pereira GM (2016) Physiology and postharvest of pepper fruits. In Rêgo ER, Rêgo MM and Finger FL (eds) Production and breeding of chilli peppers (Capsicum spp). Springer, Switzerland, p. $27-40$.

Geleta LF and Labuschagne MT (2004) Comparative performance and heterosis in single, three-way and double cross pepper hybrids. Journal Agricultural Science 142: 659-663.

Hasanuzzaman M, Hakim MA, Fersdous J, Islam MM and Rahman L (2012) Combining ability and heritability analysis for yield and yield contributing characters in chilli (Capsicum annuum) landraces. Plant Omics Journal 5: 337-344.

IPGRI (1995) Descriptores for Capsicum (Capsicum spp.). International Plant Genetic Resources Institute, Rome, 51p.

Juhász ACP, Rodrigues R, Sudré CP and Pereira MG (2009) Detecção de ação gênica epistática no controle genético de características agronômicas em pimentão. Magistra 3: 203-210.

Khodadadi M, Fotokian MH and Miransari M (2011) Genetic diversity of wheat (Triticum aestivum L.) genotypes based on cluster and principal component analyses for breeding strategies. Australian Jounal of Crop Science 5: 17-24.

Lasmar A, Maluf WR, Ticona-Benavente CA, Nogueira DW and Nogueira DG (2019) Diallel analysis and heterosis components in páprica peppers. Revista Ciência Agronômica 50: 282-290.

Marame F, Desalegne L, Fininsa C and Sigvald R (2009a) Genetic analysis for some plant and fruit traits, and its implication for a breeding program of hot pepper (Capsicum annuum var. annuum L.). Hereditas
146: $131-140$.

Marame F, Desalegne L, Fininsa C and Sigvald R (2009b) Heterosis and heritability in crosses among Asian and Ethiopian parents of hot pepper genotypes. Euphytica 168: 235-247.

Nascimento NFF, Rêgo ER, Nascimento MF and Finger FL (2012b) Heritability and variability for port traits in a segregating generation of ornamental pepper. Acta Horticulturae 953: 299-304.

Nascimento NFF, Rêgo ER, Nascimento MF, Finger FL, Bruckner CH and Rêgo MM (2014) Combination ability for yield and fruit quality in pepper (Capsicum annuum). Genetics and Molecular Research 13: 3237-3249.

Nascimento NFF, Rêgo ER, Rêgo MM, Nascimento MF and Alves LI (2012a) Compatibilidade em cruzamentos intra e interespecíficos em pimenteiras ornamentais. Revista Brasileira de Horticultura Ornamental 18: 58-61.

Passos AR, Silva AS, Souza CS, Souza CMM and Fernandes LS (2010) Parâmetros genéticos de caracteres agronômicos em genótipos de mamoneira. Pesquisa Agropecuária Brasileira 45: 709-714.

Pessoa MAS, Rêgo ER, Carvalho MG, Santos CAP and Rêgo MM (2018) Genetic diversity among accessions of Capsicum annuum L. through morphoagronomic characters. Genetics and Molecular Research 17: 1-15.

Pickersgill B (1971) Relationships between weedy and cultivated forms in some species of peppers (genus Capsicum). Evolution 25: 683-691.

Rêgo ER and Rêgo MM (2016) Genetics and breeding of chilli pepper Capsicum spp. In Rêgo ER, Rêgo MM and Finger FL (eds) Production and breeding of chilli peppers (Capsicum spp). Springer, New York, p. 27-40.

Rêgo ER, Fortunato FLG, Nascimento MF, Nascimento NFF, Rêgo M.M and Finger FL (2012a) Inheritance for earliness in ornamental peppers (Capsicum annuum). Acta Horticulturae 961: 405-410.

Rêgo ER, Rêgo MM, Costa FR, Nascimento NFF, Nascimento MF, Barbosa LA, Fortunato FLG and Santos RMC (2012b) Analysis of diallel cross for some vegetative traits in chili pepper. Acta Horticulturae 937: 297-304.

Rêgo ER, Rêgo MM, Cruz CD, Finger FL and Casali VWD (2011) Phenotypic diversity, correlation and importance of variables for fruit quality and yield traits in Brazilian peppers (Capsicum baccatum). Genetic Resources and Crop Evolution 58: 909-918.

Rêgo ER, Rêgo MM, Finger FL, Cruz CD and Casali VWD (2009) A diallel study of yield components and fruit quality in chilli pepper (Capsicum baccatum). Euphytica 168: 275-287.

Rodrigues R, Gonçalves LSA, Bento CS, Sudré CP, Robaina RR and Amaral Junior AT (2012) Combining ability and heterosis for agronomic traits in chili pepper. Horticultura Brasileira 30: 226-233. 
Said AA (2014) Generation mean analysis in wheat (Triticum aestivum L.) under drought stress conditions. Annals of Agricultural Sciences 59: $177-184$.

Santos RMC, Rêgo ER, Borém A, Nascimento MF, Nascimento NFF, Finger FL and Rêgo MM (2014) Epistasis and inheritance of plant habit and fruit quality traits in ornamental pepper (Capsicum annuum L.). Genetics and Molecular Research 13: 8876-8887.

Sharma A, Swain D and Sekhon BS (2017) Breeding strategies based on divesity analysis in advance breeding lines of chilli (Capsicum annuum var. annuum L.). Electronic Journal of Plant Breeding 8: 1247-1257.

Silvar C and García-González CA (2017) Screening old peppers (Capsicum spp.) for disease resistance and pungency-related traits. Scientia Horticulturae 218: 249-257.

Stommel JR and Griesbach RJ (2008) Inheritance of fruit, foliar, and plant habit attributes in Capsicum. Journal of the American Society for
Horticultural Science 133: 396-407.

Thakur M, Sood S and Gupta N (2019) Genetic analysis of quantitative and quality traits in bacterial wilt resistant genotypes of bell pepper under sub-temperate conditions of north-western Himalayas. Journal of Pharmacognosyand Phytochemistry 1: 66-73

Valentini G, Baldissera JNC, Morais PPP, Stähelin D, Heidemann JC, Stenger F, Elias HT, Guidolin AF and Coimbra JLM (2011) Herança da resistência em feijoeiro à murcha causada por Curtobacterium flaccumfaciens pv. Flaccumfaciens, Pesquisa Agropecuária Brasileira 46: 1045-1052.

Wesp CL, Martinelli JÁ, Chaves MS, Graichen FAZ and Federizzi LC (2008) Herança da resistência quantitativa à ferrugem da folha em linhagens recombinantes de aveia branca. Tropical Plant Pathology 33: 138-147.

Yunandra, Syukur M and Maharijaya A (2018) Inheritance study for yield components of pepper (Capsicum annuum L.). Earth and Environmental Science 196: 1-8. 